Clemson University

TigerPrints

Publications

Eugene T. Moore School of Education

2020

Do We Need More Productive Theorizing? A Commentary

David Reinking

David B. Yaden Jr.

Follow this and additional works at: https://tigerprints.clemson.edu/eugene_pubs

Part of the Education Commons 



\section{Do We Need More Productive Theorizing? A Commentary}

\section{David Reinking}

University of Georgia, Athens, USA

\author{
David B. Yaden, Jr. \\ 12 University of Arizona, Tucson, \\ USA
}

\section{INTERNATIONAL \\ LIERABY \\ ASSOCIATION}

Reading Research Quarterly, $0(0)$

pp.1-17 | doi:10.1002/rrq.318

(C) 2020 International Literacy Association.

\begin{abstract}
In this commentary, we argue that literacy research would be more productive if researchers had a clearer, more nuanced understanding of theory. Specifically, we argue that theory in a practice-oriented field is most fundamentally productive when it provides instrumental guidance for literacy beyond academic understanding about literacy. Premises for that argument are presented, as well as how productivity connects to an instrumental view of theory within the philosophy of science. We provide examples from authoritative sources and relevant studies suggesting that conceptions and uses of theory in literacy research are ambiguous, diffuse, and incoherent. We argue that productivity could be a unifying construct to ameliorate those limitations. To stimulate discussion about theory, we propose several ways that theorizing might be more productive. Those proposals comprise a critique of theorizing in the field and illustrate how more productive theorizing could close the gap between research and practice. Finally, we discuss how our proposals might be implemented in the field's research.
\end{abstract}

It is one of the shibboleths of educational research that theory...[is] valuable, if not essential. But if the morphology of theory is inconstant...its chameleon-like nature will allow it to escape serious scrutiny. (Thomas, 1997, p. 83)

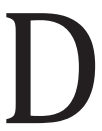

octoral students in the field of education, who are typically for- mer educators, discover early in their studies that embracing theory is a hallmark of their entry into academia. Labaree (2003)

argued that a movement from a practical to an analytically theoretical orientation is the fundamental challenge of preparing doctoral students in education to transition from being educators

to becoming education researchers (cf. Bulterman-Bos, 2008). Contributing to that end, a clas- sic text for literacy researchers, in its seventh edition and often required reading for doctoral students, is Theoretical Models and Processes of Literacy (hereafter TMPL; Alvermann, Unrau, Sailors, \& Ruddell, 2019). It is unimaginable that promising new literacy researchers could not elucidate theoretical positions that inspire and provide meaning and guidance to their work. No doctoral dissertation is likely to be approved without some invocation of relevant theory (cf. Boote \& Beile, 2005), and manuscripts and conference papers reporting

research can be sum- marily rejected if they lack a theoretical grounding. Yet, the former edi- tors of a leading literacy research journal (Anders, Yaden, Iddings, Katz, \& Rogers, 2016) editorialized that the greatest concern across approxi- mately 600 manuscripts reviewed during their editorship 
was "the need for literacy

researchers to more clearly explicate the conceptual foundations of the theories invoked and subsequent impact of those theoretical 
frameworks upon design, analysis, and interpretation

the studies conducted" (p. 3).

Given that theory is a touchstone of literacy research,

it seems reasonable to expect a consensual

understanding

of precisely what it is and what role theorizing

plays in

our work. We would expect some agreement, for exam-

ple, about responses to questions such as the following:

Toward what ends do we engage in theorizing, and spe-

cifically, how does it serve the ultimate goals of the field?

Are there particular views of theory that might be more,

or less, meaningfully valid in literacy research as a

prac-

tice-oriented field? Also, as implied by our title, are

some

theories and uses of theory more productive than

others?

In this commentary, we address such questions, propos-

ing productivity as a unifying construct that might deepen our collective understanding of theory and better

align theorizing with the ultimate goals of the field.

Our

motivation is derived partially from evidence, presented

in a subsequent section, that, in the field of literacy

research, the term theory has been used too loosely and

amorphously and has lacked coherence, and thus, is sub-

ject to the critique that the introductory quote suggests.

We frame our argument as a commentary

because,

according to Trimbur (2013), it "is a genre of writing that

uses analysis and interpretation to find patterns of mean-

ing in events, trends, and ideas" (p. 283). A

commentary

allows us to make an argument traversing a diverse

litera-

ture, allowing for more speculation and opinion than other genres of scholarly publication. Also, although we

do not wish to press the point too strongly, a

commentary

seems consistent with our career-long involvement

in

diverse aspects of literacy research and theorizing, includ-

ing conducting large-scale funded research projects, pub-

lishing, editing, reviewing, and mentoring. Nonetheless, we humbly realize that others, equally experienced, might offer reasonable counterarguments to the perspectives

37 and interpretations that we present. Our goal is not to win

38 an argument but to initiate what we believe to be a much-

39 needed, and overdue, dialogue about the role of theory and theorizing in the field. 41

42

\section{Premises About}

\section{Productivity}

45

\section{Than}

46

54 construct with many 55 theories that

Tobe produc-

\section{Productive Theorizing Is More}

\section{Claiming a Theory}

3 We believe that an awareness and understanding of theory,

if it is to be productive, must go beyond simply claiming

one and comparing or contrasting individual

might frame and inform a body of research.

tively theoretical, we believe, means something more. It means understanding the nature, role, and potential contributions of theory, as well as its pitfalls. It means understanding that theory is a multifaceted 
uses and meanings, and it means being precise about how theory is defined and used when it is invoked. For example, Chambers (1992; see also Thomas, 1997) identified nine clusters of meanings for theory in education research. These meanings included hunches, heuristic speculation, dogmatic beliefs, and explanations of empirical data. Theory and the role of theorizing in research have also been contentiously debated in the physical sciences for decades (e.g., Feyerabend, 1970; Godfrey-Smith, 2003;

Horwich, 1993; Kuhn, 1962; Morris, 2018; Popper, 1959; Richards \& Daston, 2016) and also in the social sciences (see Chambers, 1992; Lincoln, Lynham, \& Guba, 2018; Thomas, 1997). We believe that some of these meanings and uses of and perspectives about theory, given the nature and goals of literacy research, may be more productive, and others less so. If so, a first step in considering productive theorizing is for literacy researchers to explain what exactly they mean by theory and why they believe a particular meaning is well suited to the goals of their work. This com- mentary aims to contribute to that consideration.

\section{A Productive Theoryls Useful in Accomplishing Goals}

Box (see Box \& Draper, 1987), a prominent statistician, introduced an aphorism that captures the essence of theo- retical productivity: "Essentially, all models [and theories] are wrong, but some are useful" (p. 424). Similarly, poly- math Bateson (1979) stated "that there are better and worse ways of constructing scientific theories, and in insisting on the articulate statement of presuppositions so that they may be improved" (p. 29). Consistent with these views, even a wrong or incomplete theory can usefully advance understanding and reliably meet practical chal- lenges (e.g., Einstein's theory of gravity replaced Newto- nian physics, but the latter is productively useful in many situations). Fundamentally, then, a productive theory is a useful one, employed with a humble awareness that it is likely incomplete and, at least occasionally, entirely wrong.Yet, useful in what sense? We believe that a useful theory is one that contributes to accomplishing the ultimate goals ofour research. Yet, what are the goals of education/literacy research?

\section{Productive Theory Enhances Personal and Societal Well-Being}

We agree with Unrau, Alvermann, and Sailors (2019), who stated in TMPL that a central goal of theorizing should be "to formulate new literacy theory that aligns with evidence and promises better outcomes in our schools and universities" (p. 30). That goal aligns with Hostetler's (2005) position that, most fundamentally, good education research enhances people's well-being. Or, as Ranis (2009) stated, "education research is a field that 

inherently honors research for the social good" (p. 129). Thus, productive theories in education research in gen- eral and literacy research in particular are ultimately theories that facilitate conducting, interpreting, and applying research that enriches people's, and by exten- sion societal, wellbeing, most often in educational con- texts. Productive theories, then, serve socially pragmatic goals (see Dillon \& O'Brien, 2019). What constitutes well-being and the social goals that enable it may be con- tested, and should be, within democratic societies. Yet, productive theories facilitate, in practice, agreed-upon values and goals.

Less productive theories are those that do not sub- stantively advance, or distract researchers from, striving for that overarching goal. Thus, productive theories should be more than attractive abstract academic con- structs that are intellectually satisfying; they should be demonstrably useful toward enhancing literacy, however it might be defined, as a means for improving personal and societal well-being. However, we do not take the stance that less productive theories have no value, only that making a distinction between more and less produc- tive theories, specifically in terms of enabling societal well-being, would be beneficial to the field. It would help ensure that literacy researchers accept responsibility for and remain focused on the field's ultimate goals. Moving such a distinction into the consciences of researchers and the culture of literacy research would, we believe, stimu- late more productive research and theorizing.

\section{Distinguishing Theoryfor and About Literacy Is a Dimension of Productivity}

We believe that the contrasting prepositions in the head-ing above capture a useful distinction that lays a founda- tion for considering theory's productivity (cf. Biesta \& Burbules, 2003; Labaree, 2004; Phillips, 2009). Such a dis-tinction is justifiable, we believe, because contrasting the- ory and research about literacy and for literacy might, in one sense, be analogous to the distinction between psy- chology and applied psychology or between linguisticsand applied linguistics (Labaree, 2004). Phillips (2009) made a similar distinction between education research and education scholarship. Education research, and liter-acy research carried out under its umbrella, is inherently applied research aimed at finding ways to better achieve educationally valued outcomes and goals. Education researchers hold themselves accountable for engaging in work that advances the goals of education. Education researchers, typically and appropriately, have had first- hand involvement in education practice at some level, and they are the mainstay of faculty in schools and col- leges of education and in education agencies. Similarly, literacy researchers who are education researchers do research for literacy, seeking theories that productively 
advance literacy as an educational endeavor carried

out

mainly by teachers and others in the realm of practice.

Education scholarship, in contrast, aims to better

understand aspects and issues of education, or literacy,

with grounding in disciplines such as history, anthropol-

ogy, sociology, political science, psychology, economics, and philosophy. Education scholars view education as

essentially a societal institution and those involved in

aspects of that institution as enactors to be studied, rather

than agents to be informed. Education, or literacy, scholar-

ship does not necessarily assume responsibility for improv-

ing practice, although it may aspire to do so.

Scholarship

also includes critiques of education, or literacy, and its

practice, sometimes focusing on its shortcomings,

limita-

tions, and unmet challenges, but less often on how to

rec-

tify them. That is, education scholars interested in

literacy

do work about, not necessarily for, literacy. Their

work

may offer needed perspective while expanding

awareness

and understanding of the multiple, fascinating

dimensions

of literacy.

However, we wish to highlight several caveats.

First, we

emphatically do not propose this distinction as a

dichot-

omy. Instead, as we illustrate in a subsequent section,

we

conceptualize this distinction as a matter of

emphasis

existing fluidly and dynamically across a

continuum-a

distinction more of degree than of fixed kind. Put

another

way, we are not advocating for theories being sorted

into

clearly demarcated buckets, as one reviewer of an

earlier

version of this article suggested.

Further, as we illustrate and discuss in a

subsequent

4 | Reading Research Quarterly, 0(0) section, the interplay of theorizing across a continuum about and for literacy can enhance productivity. For example, theories about literacy can reveal hidden or ignored dimensions of literacy and establish valued goals or a guiding moral conscience for literacy research, or as

3 Suppes (1974) argued, what is superficial and what is important. Many theories imported into literacy research from other fields and disciplines seem to serve this latter purpose, such as postcolonial theory (literary theory), 5 critical race theory and intersectionality (legal studies), posthumanism (philosophy, literary criticism, and artificial intelligence), semiotic mobility (semiotics), discourse communities (linguistics), spacetimemattering (poststructural feminism), and third space and positioning theory (social psychology). However, as we argue in a subsequent section, such theories might be more productively moved from the realm of pure scholarship about literacy to the realm of research for literacy.

The dynamic interplay between theories about and for literacy on a continuum is also consistent with the stance of Stokes (1997), who argued that the distinction between basic and applied research is a false dichotomy leading to the inaccurate and misleading perception that basic research is foundational to and drives applied research, even in the hard sciences. More typically, new fundamental 
theoretical insights emerge from systematic attempts

address the practical challenges of achieving a soughtafter

goal. For example, aeronautics arose from the Wright

brothers attempts to go beyond theories of lift to

enable

controlled flight. Theories of microbiology (and the

undo-

ing of inaccurate theories that chemical, not biological, processes were involved) emerged from Pasteur's

efforts to

preserve food. Statistical theories and procedures were

developed in the context of improving agricultural yields.

Finally, we acknowledge that literacy is a broad and

multidimensional area of study, and we hold a strong com-

mitment to academic freedom among our colleagues

who

wish to pursue any of its dimensions and any theories,

about or for literacy, that they deem relevant.

Nonetheless,

an awareness of a distinction between literacy theory

and

research for and about literacy may add a more

nuanced

perspective to the field's theorizing, reminding literacy researchers that, to be productive, theory must continually

move toward achieving the goals of an applied

\section{Productive Theories Are Consummated in Practice}

Hoadley (2004) introduced the term methodological

align-

ment, which we believe speaks to productive

theorizing in

an applied field. Alignment, in his view, is an

overarching

and coherent body of work that is not complete

until it

speaks directly to achieving practical outcomes. Such

alignment has implications for theory because, as

Hoadley

argued, "carry[ing] ideas all the way from explanation

to

prediction to falsification to application [emphasis

added]

seems like the missing link in educational research that

will

ensure our theories have practical implications" (p.

205).

Put another way, in an applied field such as

education, theorizing is not consummated, and thus not fully produc-

tive, until it can demonstrate practical utility.

In this view,

grand, abstract theories about literacy and its multiple

dimensions (theories about literacy), and the work they

inspire, are productive only when embedded within a pro-

gram of research ending in practical utility.

Conversely,

productive theorizing in an applied field is

limited when

overarching theories about literacy are

isolated or discon-

nected from a consideration of theories for

literacy. Failing

to make this distinction, we believe,

constitutes less produc-

tive theorizing and sustains the frequently

acknowledged

gap between research and practice. However, lest Hoadley's

(2004) and our point be misunderstood, consummated

theorizing is not productively achieved in a

final sense only

through conventional experiments.

Demonstrating, exper-

imentally, the effectiveness of instructional interventions

may be productively useful in making generalizations

across contexts. However, even more

productively useful

for practice are finer tuned contextual

understandings

related to process-how goals are achieved

(see Pressley,

Graham, \& Harris, 2006). 
There are prominent historical and more contemporary examples of Hoadley's (2004) notion of alignment in the field, illustrating how theorizing and research can move productively from about to for literacy. LaBerge and Samuels's (1974) general theory of attention and automatic- ity from the field of educational psychology led Samuels (1979) to develop repeated reading as a theory-based instructional activity to enhance reading fluency and com-prehension. Brown and her colleagues (e.g., Brown, Armbruster, \& Baker, 1986) conducted theoretical and empirical work on metacognition. Her laboratory research about literacy led her to develop reciprocal teaching (Palincsar \& Brown, 1984) and inspired strategy instruction (in effect, a pedagogical theory for literacy) as an approach to teaching reading comprehension. Yet, Brown (1992) had a palpable awareness that the methods and theories that guided her laboratory work were not productive in guiding attempts to move her laboratory findings into classrooms, leading her to seek new methodologies and new theories of implementation for literacy. Specifically, she replaced the experimental methods of the laboratory work with what she termed design experiments, mixing quantitative and qualita-tive approaches, to develop pedagogical theory. For exam- ple, she theorized from her data that reciprocal teaching was more effective when students took a more active role in their own learning and teachers were positioned as guides rather than dispensers of knowledge.

Heath (1983) is another example. She used anthropo- logical methods to develop theories about literacy in rural Appalachia, which became foundational to informing her efforts to enrich literacy there. More recently, Lee (2013) used theory about African American students' mental models of language to develop instructional activities that used their vernacular to enhance responses to literature. A special case is Rosenblatt's (e.g., 1994) transactional theory of textual meaning and purposes. Although an abstract theory about literacy, it contained easily under-stood metaphors (e.g., the transaction between a river and its banks) with transparent implications for pedagog-ical practice. Similarly, González, Moll, and Amanti (2005) proposed funds of knowledge as a theory with clear implications for classroom practice and enhancing social justice. We believe that productive theorizing in the field would be enhanced if these examples were emulated as an expected progression in moving theories about lit- eracy to for literacy.

\section{Problems With Theory and Theorizing in Literacy Research}

In this section, we provide examples suggesting that many theories within the field's literature are nebulously defined and incoherently applied. As a commentary, we do not offer a comprehensive review, only prominent examples in 
support of an arguable position for proposing productivity as a needed, potentially ameliorative construct. We argue that the problems we highlight here are symptomatic, if not causal, in limiting theoretical productivity. Thus, we estab- lish conditions suggesting the need for a clarifying con- struct such as productivity, and we set the stage for defining productivity and offering proposals for increasing it.

\section{Lack of Terminological and Conceptual Clarity}

Ambiguities, concerns, and even contradictions about theory in the field's literature are not difficult to find. For example, disciplinary literacy (e.g., Moje, 2015), reading engagement (e.g., Baker, Dreher, \& Guthrie, 2000; Guthrie, 2004), and new literacies/multiliteracies (e.g., Coiro, Knobel, Lankshear, \& Leu, 2008; Kalantzis, Cope, \& Cloonan, 2010) have each been labeled interchangeably as theories or perspectives. In addition, translanguaging has been called a conceptual framework (MacSwan, 2017), a practical theory (Wei, 2018), as well as an ideol- ogy, a theory of bilingualism, a pedagogical stance, and a set of practices (Mazak, 2016). Whole language, across decades, has been called not only a theory but also a per- spective, a philosophy, a movement, a set of principles, an approach, and a curriculum (cf. Chen, Cheng, \& Chou, 2016; Goodman, Fries, \& Strauss, 2016; Ridley, 1990). However, given the gravitas of theory, ambivalence often trades on hybrid terms such as theoretical perspective or emerging theory. Yet, we can find no precise explication of how such terms differ from the term theory. For example, we wonder what criteria must be met for an emerging theory to become a full-fledged one or how a theoretical perspective differs from a theory.

\section{Previous Attempts to Clarify Theory}

In an early attempt to impose order on theorizing in liter- acy research, De Beaugrande (1981) offered 16 design cri- teria for establishing valid and useful theoretical models of reading processes. Within an information-processing paradigm, he suggested that models should be evaluated on criteria such as the nature of processor contributions (i.e., bottom-up vs. top-down approach), type of memory storage (abstraction, construction, and reconstruction), utilization (complete vs. partial analysis of text elements), and so forth. After comparing nine reading and language processing models, including his own, De Beaugrande's conclusion was that no model of text processing provided an optimal explanation for complex language and literacy processing. However, we can find no prominent examples of his criteria subsequently being used widely to develop or apply theory.

Subsequently, Mosenthal (1984) claimed that the interpretation of theories in reading were increasingly 
problematic because (a) literacy theorists are selective in

what elements they choose to define and operationalize

in their literacy models, and more importantly, (b)

theo-

ries and models must be understood in light of the socio-

political orientation of those who formulate them.

Given

this selectivity and the diversity of ideological

orienta-

tions, Mosenthal concluded pessimistically that

"until

this sociopolitical process is understood, the question

of

what reading is will continue to be unresolved" ( $p$. 221).

We again find no evidence that the field

subsequently

attempted to resolve these problematic aspects of theory

development and interpretation.

A decade later, Cunningham and Fitzgerald (1996)

encouraged the literacy community to evaluate

theories

and claims about literacy in relation to researchers'

episte-

mological orientations. For example, Cunningham

and

Fitzgerald contrasted Rumelhart's $(1977,1985)$

interactive,

hypothetico-deductive model of reading with

Rosenblatt's

$(1968,1994)$ transactional, contextualist view. They

then

listed benefits of evaluating reading research

according to

the respective epistemological orientations, thus

enabling

researchers to "see that there are multiple ways of

consid-

ering knowledge, each of which may potentially be valid"

(Cunningham \& Fitzgerald, 1996, p. 58). Although

their

work was often cited and furthered conceptual clarity,

we

find no convincing evidence that it had widespread

or

long-lasting influence on theorizing in the field. In fact,

more contemporary sources, to which we now turn,

sug-

gest continued ambiguity.

Current Ambiguities on Uses of Theory

8 | Reading Research Quarterly, 0(0)

16 in Research

1 To the extent that there is clarity about theory, we would expect to find it in two authoritative and widely used vol-

2 umes in the field: the seventh edition of TMPL (Alvermann et al., 2019), the classic archival reference pitched toward

3 researchers, and the third edition of Tracey and Morrow's (2017) Lenses on Reading: An Introduction to Theories and Models (hereafter $L R$ ), which is aimed more at practitioners. However, both volumes embrace an accommodating eclecticism, if not unsettling ambiguity, toward theory and its role. For example, in their introductory chapter framing TMPL, Unrau et al. (2019) portray theory in terms of classical science (e.g., as reflecting reality, having truth value, and producing durable generalizations). Yet, they also acknowledge that theories are subjective, interpretivist, and ideological and that the editors' placement of chapters in the volume may not "remain accurate over time as ideologies evolve" (p. 9). LR's authors also see theories both as "explanations for why they [researchers] expect something will happen" (p. 9) and as lenses through which the world can be viewed.

Yet, in our view, the stance most oppositional to productivity - a stance shared across these volumes-is 
1 that researchers are free agents who choose theories

based

2 on their personal views about and dispositions

toward lit-

eracy. In TMPL, for example, Unrau et al. (2019) state

that

the book's purpose is to help "readers think through

vari-

ous dichotomies and differences in the field of

literacy

research to discover what perspectives they find

compati-

ble with their present knowledge and beliefs" (p. 4). In

$L R$,

the authors similarly suggest that for researchers,

there is

no one correct theory for framing their work and,

specifi-

cally, that "researchers can choose [emphasis added]

from

a wide variety of theoretical perspectives...available

[emphasis added] to them" (p. 9). These exhortations to

literacy researchers seem unproductively solipsistic, even

unnecessarily anarchic (see Feyerabend, 2010), especially

in a practice-oriented field that ostensibly looks to

research for productive guidance. An apt analogy

might

be shopping in a department store for clothing that

one

finds attractive or that fits one's personal style, as

opposed

to going to an outdoor store to find functional

clothing

suitable for challenging terrain or inclement weather

to be

encountered on a wilderness adventure.

Further, unproductive theorizing may be exacerbated

when, as is clearly the case in these two authoritative vol-

umes, most of the theories highlighted are imported

from

other fields and weighted toward theories about

rather

than for literacy. Neither volume critiques the

pedagogi-

cal utility of these imported theories, nor are there

justifi-

able caveats about whether literacy researchers are

sufficiently familiar with such theories when

applying

them to literacy. That issue has been raised in the

litera-

ture. For example, despite the extensive literacy research grounded theoretically in Vygotsky's work, literacy schol-

ars deeply familiar with his work have argued that it has

been mostly misread among literacy

researchers (e.g.,

Yaden, 2017). 36

Smagorinsky, 2011;

\section{7}

Empirical Evidence That Theory

Is
39

40

41

42

43

44

45

46

47

48

49

50

51

52

53

54

55

\section{Problematic in Literacy Research}

Two studies investigated how theory has been used in the

field's research literature. Taken together, they reveal

problems and concerns about the coherency and produc-

tive use of theory in the field's literature across almost

three decades.

Dressman (2007) analyzed how theory was posi-

tioned in 69 articles published between 1992 and 2003 in

three leading literacy research journals

Uournal of

Reading Behavior/Journal of Literacy

Research, Reading

Research Quarterly, and Research in the

Teaching of

English). Among his conclusions were that

(a) "in some

instances it was difficult to separate what

was 'theory' and

what was 'research"' (p. 341); (b)

researchers typically

positioned their work in relation to more

than one theo-

rist, making it difficult to integrate the

report into a uni-

fied whole; and (c) "the nature of the

relationship that 
authors developed between their findings and the way that theory functioned to define, support, or challenge the meaning constructed from those findings varied widely" (p. 344). Finally, he found that theory was used within four different overarching frames: (1) a broad plat- form for framing a research agenda, usually in the intro- duction; (2) a foundational apparatus used in the introduction and discussion, but little in between; (3) a discursive scaffold, with explicit alignment of theoretical precepts to data throughout the report; and (4) a dialecti- cal scaffold creating a persistent tension between or among theories and data.

Dressman's (2007) overall conclusion is particularly relevant to our argument. Although the application of theory in the articles he analyzed created a rich intellec- tual narrative, they were "lacking in practical usefulness or advancement of general knowledge about a phenome- non" (p. 349). He found theory used frequently as a war- rant for the study itself, rather than as a warrant for specific findings. Theory as dialectical scaffold, which created an inherent tension between theory and data, was the only category that created an opportunity for connecting empirical data to building new, consequential theory or refining existing theory. However, that category contained only nine of the 69 studies. Social theories, in contrast, were used typically as a rhetorical frame to establish that a perspective, topic, or question mattered. Thus, the relation between the theory and the data formed a closed system. Theories frequently represented more of a passionate idealism, with little commitment to further- ing understanding based on empirical data-steering "toward the stars rather than by the stars" (Alexander, 2000, as cited in Dressman, 2007, p. 353). He concluded that this common orientation represented a lack of skep- ticism about how theoretical constructs and data were related.

More recently, Parsons, Gallagher, and the George Mason Content Analysis Team (2016) analyzed the top-ics, theoretical perspectives, research designs, and data sources of more than 1,200 articles in nine peer-reviewed literacy journals. In their initial analysis, they reported categorizing the theoretical perspectives using those iden- tified in the aforementioned authoritative sources on the- ory (TMPR and $L R$ ). However, Parsons et al. found that nearly half of the articles' initial codes were labeled other. Adopting a more stringent approach, Parsons et al. cate- gorized theory only when it was explicitly named and connected to interpreting data. Notably, that approach resulted in $76 \%$ of the articles having an unspecified the- ory. Parsons et al. concluded that a reliance on implicit theoretical perspectives suggested that literacy research-ers felt no compulsion to be more explicit, because they were operating within thought collectives (Fleck, 1979).

In summary, we believe that this brief overview of work across almost four decades provides sufficient 
evidence to justify continued concern about the status androle of theory in the field. Problematic ambiguities and documented limitations remain unaddressed, directly and systematically. We, unfortunately, agree with Calfee's (2014) assessment that "the field lacks a coherent disciplin-ary core, and so is vulnerable to the emergence of a virtu- ally unlimited variety of claims, afflictions, and remedies" (p. 9). Focusing on theory and its role in terms of produc- tivity, we believe, could be a unifying ameliorative frame.

\section{Conceptualizing and Defining Productivity: An Instrumental View}

Technically, productivity is an economic concept referring to efficiency in producing valued goods and services. We use the terms productive and productivity metaphori- cally to mean efficiency in generating useful knowledge in conjunction with achieving valued goals within a prac- tice-oriented field. Although only a working definition, we believe that considering productivity in this sense could initiate a needed dialogue about theory among lit- eracy researchers. The premises we outlined earlier in this commentary and the proposals we offer in a subsequent section flesh out our ideas about productivity. In this sec- tion, we take a rudimentary step toward a more precise definition grounded in the philosophy of science.

\section{Productivity as an Operational Construct of Instrumentalism}

In the philosophy of science, there are ongoing, conten- tious theories about theories and the role of theorizing (see, e.g., Godfrey-Smith, 2003). Alternative theories about theory, and the debates that they inspire, primarily revolve around epistemological differences about what constitutes knowledge, truth, and justifiable belief, which are often manifested in allegiances to methodological approaches and research paradigms (Dillon, O'Brien, \& Heilman, 2000). Cunningham and Fitzgerald (1996) dis- cussed how this broad array of epistemological differ- ences about theory might apply to literacy research, including instrumentalism, which we see as a logical foundation for the construct of productivity and well matched to the goals of a practice-oriented field. These and other similar sources point to the complex entangle- ments among views of science, conceptualizations of the- ory, and the methods used to conduct research, and thus to the potential utility of a single unifying construct.

Instrumentalism has its roots in American pragma- tism as advanced by John Dewey. Although, as Sleeper (1986) argued, instrumentalism played a subordinate role in Dewey's larger philosophical frame of transactional 
realism (see also Boyles, 2012), that frame included "an

involvement that is causally efficacious" (p. 3). As

Biesta

and Burbules (2003) stated,

the central idea of Dewey's pragmatism [is] that knowing

and

acting are necessarily related...[and that] the (alleged)
separa-

tion between theory as the domain where we acquire

knowledge

independent of our activities, and practice as the domain

where

we apply this knowledge, can no longer be sustained. (p. 86)

Further, they stated that, for Dewey, "the difference

between theory and practice is only a functional and

gradual distinction" (p. 87) and that "the point of knowl-

edge is not to know more simply for the sake of

knowing,

but to be able to exert greater control over the

problem-

atic situations we find ourselves in" (pp. 97-98). In

short,

theorizing is inseparable from practice, and from

an

instrumental view, it is reasonable to consider how

theory

might productively influence, guide, and indeed,

reflect

practice. Instrumentalism implicitly privileges theory

that

can be applied for literacy and counters the historical

sep-

aration in education research between research and

prac-

tice (Lagemann, 2000).

Thus, productivity can be conceptualized as a related,

but separate, construct that flows naturally from an

instru-

mental view of theory associated with Dewey and

other

pragmatists. We are not proposing productivity as a

new,

alternative theory about theory, nor do we believe that

it is

necessary to do so. Instead, we see productivity as

useful

because it holds theorizing accountable to the

underlying

rationale of instrumentalism. Productivity makes

the

abstractness of instrumentalism concrete. It presses

for

12 | Reading Research Quarterly, operationalizing the benefits that instrumentalism suggests theorizing can serve in practice. For example, productivity implicitly asks, How can we productively frame our theories as instrumental to achieving the goals of a practice-oriented field dedicated to developing literacy? To what extent have we been successful in achieving specific goals, and are we being successful? What are reasonable indicators of progress or the lack thereof?

Further, productivity more explicitly suggests discussions about what exactly our goals are, why they are valued, and the degree to which we have consensual, or at least coherent, understandings about the endpoints of our theorizing. As Dillon and O'Brien (2019) stressed, pragmatism is much more than achieving what works; it entails an explicit consideration of what is desirable. Productivity, as a construct, highlights that issue more than instrumentalism alone. That is, producing many products efficiently, if those products have little value, is not productive. It is also in this sense that productivity allows space for theories about literacy. Theories about literacy may not always be fully productive in their own right, but they can help clarify values and identify factors that might efficiently instantiate them. Nonetheless, achieving, not simply identifying and clarifying, values is 
the ultimate measure of theoretical productivity in a

tice-oriented field.

A good example of this relation between theories about and for literacy is the questioning of deficit models

of literacy grounded in sociocultural theories, such as funds of knowledge (e.g., Moll, 1990; Moll \& González, 2004) and cultural-historical activity theory (see, e.g.,

Gutiérrez, Morales, \& Martinez, 2009), both of which are

theories about literacy and were imported from cultural

anthropology. Yet, these theories have immediate impli-

cations for shifts in pedagogical perspective and have productively inspired research into how they can be implemented in practice (see, e.g., Rodriguez,

\section{Productivity Mitigates Limitations of Theorizing}

There are other advantages when productivity is linked to instrumentalism as an expression of pragmatism. For example, Dillon et al. (2000) argued that a pragmatic stance defuses paradigmatic disputations that distract researchers

from conducting research that is "prone to making a differ-

ence in students' learning and teachers' pedagogy" (p. 25),

thus increasing productivity. Productivity might also miti-

gate two general limitations of theorizing. Phillips and Burbules (2000) reported an experience that illustrates these limitations. They asked two doctoral students, one a

Freudian and the other a behaviorist, to provide commen-

taries on a video about an autistic woman. Phillips and Burbules found "an amazing disparity-[the students] noticed quite different things (often ignoring events and features that the other pointed to as being significant), and of course they used quite different terminology to speak

about what they were seeing" (p.16).

The example illustrates the limitation of theoryladen perception (e.g., Hanson, 1958), where commitment to a theory dictates what is noticed. Established or

preferred

theories can limit, and delimit (cf. Mosenthal, 1984), what

data are observed, how they are interpreted, and even what studies are conducted and how they are designed.

Theory-laden perception can distort understanding the fullness of phenomena and may inhibit researchers from generating new, potentially more useful theoretical perspectives. A strong, even unshakable, attachment to a

theory may set up a closed system in which the evidential

checks and balances that act as a selfcorrective for inadequate, incomplete, or incorrect theories are suppressed.

Productivity may help researchers resist becoming uncrit-

ical devotees of attractive theories. Instead, they would

become more open-minded problem solvers seeking theories that demonstrably move the field forward, ultimately enhancing practice toward achieving valued goals. A second limitation is incommensurability (e.g., Feyerabend, 1970; Hacking, 2012; Kuhn, 1962), illustrated in the example when students used different discoursesto 
describe what they saw. Using incommensurate terms and language inhibits potentially productive interactions among researchers using diverse theories and perspec- tives. That limitation is amplified when there is a broad palette of theories from which to choose. In the extreme, an entire field may become balkanized and separated into thought collectives (Parsons et al., 2016), thus restraining productivity. In that vein, Calfee (2014) characterized the field as "like the Tower of Babel, [where] the inhabitants speak different languages and communication can be a challenge" (p. 9). Considering the productivity of theory and theorizing might mitigate such incoherency, encour- aging researchers to build bridges across their differing terminologies, discourses, and disciplinary perspectives (see Almasi, 2016).

\section{Proposals for More Productive Theorizing}

Guided by the issues raised in the previous sections, we propose several ways that theorizing in literacy research might be more productive. We offer the following pro- posals, not prescriptively but to initiate conversations that might lead to more productive theorizing.

\section{Conceptualize Theorizing on a Continuum Between Theories About Literacy (Literacy Scholarship) and Theories for Literacy (Literacy Research)}

Figure 1 is a purely illustrative continuum that helped us clarify our thinking and that might be useful for initiating discussions about the role of theory and productive theo- rizing in the field. The figure has several hypothetical ele- ments related to issues raised in this commentary. The main element is conceptualizing theories on a continuum from theories about literacy to for literacy. We then added hypothetical categories along that continuum to illustrate that as theorizing moves from about to for literacy, theories become less abstract and more instrumental to informing practice. These categories also illustrate comparable move- ment from theories that are exogenous to education and literacy to those that are endogenous. Finally, we created a vertical continuum from broad, general theories to narrow, specific theories, highlighting the latter that are more directly related to literacy research. In general, then, theo- ries that fall naturally (or can be moved, as we discuss in the subsequent section) toward the upper right area of Figure 1 are more productive in a practice-oriented field.

The specific examples of topical areas of theory or spe- cific theories offered within the boxed areas are decidedly idiosyncratic to our own knowledge and experience. 
FIGURE 1

Conceptualizing Theoretical Productivity in Literacy Research on a Continuum With Hypothetical Components, Domains, and Examples

\begin{tabular}{|c|c|c|c|c|c|c|c|}
\hline \multirow{3}{*}{$\begin{array}{l}\text { Theories } \\
\text { about literacy } \\
\text { (literacy } \\
\text { scholarship) }\end{array}$} & \multicolumn{6}{|c|}{$\begin{array}{c}\text { Abstract conceptual theory } \rightarrow \text { Instrumental theory for practice } \\
\text { Theory exogenous to education (literacy) } \rightarrow \text { Theory endogenous to education (literacy) }\end{array}$} & \multirow{3}{*}{$\begin{array}{l}\text { Theories } \\
\text { for literacy } \\
\text { (literacy } \\
\text { research) }\end{array}$} \\
\hline & \multirow{3}{*}{$\begin{array}{l}\text { Academic } \\
\text { disputation }\end{array}$} & \multicolumn{3}{|c|}{ Hypothetical theoretical domains } & \multirow[b]{2}{*}{$\begin{array}{l}\text { Currricular } \\
\text { influence }\end{array}$} & \multirow[b]{2}{*}{$\begin{array}{l}\text { Pedagogical } \\
\text { practice }\end{array}$} & \\
\hline & & $\begin{array}{l}\text { Functional } \\
\text { process }\end{array}$ & $\begin{array}{l}\text { Sociocultural } \\
\text { context }\end{array}$ & $\begin{array}{c}\text { Pedagogical } \\
\text { factors/context }\end{array}$ & & & \\
\hline \multicolumn{6}{|c|}{ Examples of topical areas/theories } & & \\
\hline Narrow & \multirow{11}{*}{$\begin{array}{l}\text { Sapir-Whorf } \\
\text { hypothesis of word } \\
\text { meaning } \\
\text { Where is textual } \\
\text { meaning? } \\
\text { Semiotic meaning } \\
\text { Literacy vs. } \\
\text { literacies } \\
\text { Orality vs. literacy } \\
\text { Culture/power } \\
\text { relations } \\
\text { Marxism } \\
\text { Postmodernism }\end{array}$} & Automaticity & \multirow{11}{*}{$\begin{array}{l}\text { Critical literacy } \\
\mathrm{D}(\mathrm{d}) \text { iscourses } \\
\text { Vygotskian theory } \\
\text { Critical pedagogy } \\
\text { Critical race theory } \\
\text { Intersectionality } \\
\text { Postcolonialism } \\
\text { Posthumanism } \\
\text { Constructionism/ } \\
\text { constructivism }\end{array}$} & \multirow{11}{*}{$\begin{array}{l}\begin{array}{l}\text { Reading } \\
\text { engagement }\end{array} \\
\text { Readers' identities } \\
\text { Discussion of texts } \\
\text { Classroom } \\
\text { discussion } \\
\text { Children's play } \\
\text { Teacher } \\
\text { preparation } \\
\text { Teacher beliefs } \\
\text { Motivation } \\
\text { Activity theory }\end{array}$} & Phonemic & Implementing & \\
\hline & & hypothesis & & & Miscue analvsis & & \\
\hline & & Explanations of & & & Disciplinary literacy & interactions with & \\
\hline & & reading difficulties & & & Reader response & Process writing & \\
\hline & & development/ & & & $\begin{array}{l}\text { Language } \\
\text { experience }\end{array}$ & Matthew effects & \\
\hline & & Metacognition & & & Multimodal literacies & Funds of knowledge & \\
\hline & & Information & & & Translanguaging & $\begin{array}{l}\text { Culturally } \\
\text { responsive teaching }\end{array}$ & \\
\hline & & processing & & & $\begin{array}{l}\text { Technological } \\
\text { Pedagogical Content }\end{array}$ & Response to & \\
\hline & & Connectionism & & & Knowledge (TPACK) & Interven & \\
\hline & & Neurological theories & & & Learner-centered & $\begin{array}{l}\text { Inquiry/problem } \\
\text { solving }\end{array}$ & \\
\hline General & & & & & & & \\
\hline
\end{tabular}

Note. Shaded examples more directly relate to language and/or literacy. 
1 Further, trying to create the categories along the about/for

2 axis and choosing and placing examples was not easy or

completely satisfactory. We did not completely agree

with

each other or with our own respective placements

during

sequential attempts to refine Figure 1. There was

much

room for equivocation and debate. Yet, our increasing

frustration gradually gave way to the realization that

pre-

cisely establishing categories and placements within a con-

tinuum of productivity was less important than the

reflective discussion that it provoked.

Thus, we believe that Figure 1 might serve as a useful

heuristic for generating needed discussions about the role

of theorizing in the field in general and productive

theory

in particular. For example, it might be critiqued in a

doc-

toral seminar on theory where participants could

challenge

the continua, categories, and topics/examples, perhaps

substituting their own examples or creating an entirely dif-

ferent approach to conceptualizing

productivity. 19

\section{Shift Theories and Theorizing to the Practice End of the Continuum}

Beyond its acknowledged limitations, the continuum in

Figure 1 might also promote thinking about how theoriz-

ing could become more productive by (a) moving abstract, conceptual, exogenous theories further toward

the upper right area of the continuum and (b)

increasing

theories and theorizing that exist or evolve

naturally in

that area. An example of the former is social

constructiv-

ism, which we placed hypothetically near the

midpointof

Figure 1. However, Au's (1998) application of social

con-

structivism to the literacy development of students

from

diverse backgrounds moved the general theory more

spe-

cifically toward literacy practice. That movement is

con-

10 | Reading Research Quarterly, 0(0) sistent with the concept of methodological alignment

(Hoadley, 2004) and the examples provided in previous

sections (Brown, 1992; González et al., 2005;

Heath, 1983;

Lee, 2013; Rosenblatt, 1994; Samuels, 1979).

Such move-

ment is consistent with what Lagemann

(2008) termed

translational research, which she argued is

best done by

education researchers.

Considering movement on the

continuum also opens

up the possibility of acknowledging, or

arguing, that some

theories exist in a realm where they are

unlikely to achieve

meaningful productivity-maybe a dead-

end zone at the

extreme abstract end of the continuum. We

created sucha

category in Figure 1, which we labeled less

colloquially as

academic disputation. That is, some theories

may inspire

interesting intellectual debates among

academics but are

unlikely to be resolved or applied

meaningfully and pro-

ductively to practice in the foreseeable

future. Examples

might be neurological theories, which have

been argued

to be a bridge too far to inform pedagogy

(cf. Ansari,

54 Coch, \& De Smedt, 2011; Bruer, 1997; Hruby

\& Goswami,

2011; Mayer, 2017); theoretical explanations

of dyslexia, 
especially if students so diagnosed benefit from the same pedagogy as other readers having difficulties (see Elliott \& Grigorenko, 2014); and whether it is necessary to accept postmodern views of the world before endeavoring to bet- ter it through literacy (see the discussion of Rorty's post- modern synthesis in Linn, 1996). As Willingham (2008) stated astutely, "as one gets more distant from the desired level of analysis (the child in the classroom), the probabil- ity of learning anything useful diminishes" (p. 422).

\section{Increasing Local, Humble Theorizing}

Productivity can also be increased through generating, assessing, and refining theory that originates in and speaks directly to practice. Cobb, Confrey, diSessa, Lehrer, and Schauble (2003) referred to such theories as humble or local; "theories...are humble not merely in the sense that they are concerned with domain-specific learning pro- cesses, but also because they are accountable to [creating workable instruction]" (p. 10). Such theories address the inevitable variation and complex interacting influences andoutcomes operating in classrooms. Consequently, these theories need little translation to be immediately useful to practitioners and, thus, to be instrumentally productive.

In our own work (Bradley \& Reinking, 2011; Colwell, HuntBarron, \& Reinking, 2013; Colwell \& Reinking, 2016; Howell, Butler, \& Reinking, 2017; Reinking \& Watkins, 2000; ScottWeich \& Yaden, 2017; Yaden, Gort,Martinez, \& Rueda, 2019; Yaden et al., 2015), we engaged in such theorizing as we worked with teachers to imple- ment various instructional interventions in their class- rooms. We ground our work in general perspectives such as disciplinary literacy, new literacies, and multimodal literacies, which justify the pedagogical goals we seek and provide a broad frame for an intervention. Yet, as we col- lect data to determine what enhances or inhibits progress toward our goal and how consequent modifications of the intervention play out, we are able to adduce assertions or conjectures (Sandoval, 2004) that can evolve into peda- gogical theories that may be extended, refined, or replacedin subsequent research in other contexts.

However, theories that are directly relevant to peda- gogy are not necessarily local or humble. A prominent example is Ladson-Billings's (1995) pedagogical theory of culturally responsive teaching. Its scope was writ large yet with immediate implications for practice. Further, the theory inspired a wide range of investigations of how it could be productively implemented in classrooms, including several prominent studies in the area ofliteracy (see Morrison, Robbins, \& Rose, 2008).

\section{Acknowledge Ignorance and Failure as Productive Elements of Theorizing}

Strong arguments have been made that ignorance and failure propel systematic efforts to understand, predict, 
and enable phenomena (Feyerabend, 2010; Firestein, 2012, 2016; Stokes, 1997). In engineering science, investi- gating failure is often an essential, and therefore planned, component of creating workable solutions and furthering understanding (e.g., wind tunnels identify the conditions that can cause an airplane wing to fail; see Petroski, 2012). In practiceoriented fields such as education, failure need not be created or induced, as it is inevitable (Bryk, Gomez, Grunow, \& LeMahieu, 2015). Studying failure can gener- ate useful pedagogical theories about when and why fail- ure occurs, and ignoring it undermines productivity. As Walker (2006; see also Bryk et al., 2015) argued, "every form of practice degrades under severe conditions. We need [pedagogical theories that allow practice to] degrade gracefully rather than catastrophically" (pp. 12-13). Likewise, Wagner (1993) argued that education research and theorizing are more appropriately viewed as reducing ignorance rather than finding a truth that negates failure. Focusing on failure in practice inherently means acknowledging ignorance about how to address it. Thus, we propose moving theorizing into the realm of failure and ignorance about practice, a realm that is virtually an empty set in the field's literature, although there are tacit exam- ples. Samuels (1981) and Hoffman and Rutherford (1984) identified factors associated with unexpectedly high read-ing achievement in disadvantaged schools. Payne (2008) documented the consistent failure of education reforms introduced in urban schools, synthesizing factors common to those few that succeeded. In our own work (Colwell et al., 2013), we reported reasons for why a pedagogical inter- vention was less than successful. However, these studies only marginally, or indirectly, attended to failure.

Acknowledging and studying failure may expand productive theorizing beyond effectiveness to include factors such as efficiency (e.g., affordability, time constraints) and appeal (are teachers invested in and do stu- dents like an intervention, and why?; see Reigeluth \& Frick, 1999). This might productively distinguish opera- tional (i.e., instructional method) and structural factors (e.g., curricula, financial exigencies, teacher training, inservice opportunities) that may enhance or inhibit suc- cess (Pressley et al., 2006). It might also generate produc- tive theories from phenomenological data (see Roth, 2009) exploring, for example, what aspects of practitio- ners' professional, personal, and cultural experiences make it more, or less, likely that they will embrace or resist promising interventions or perspectives.

\section{Expect Theorizing to Go Beyond Identifying a Researcher's Perspective or Justifying a Line of Research}

In our view, productive theorizing is more than identify- ing one's perspective in conducting a research study or simply justifying a line of research. Further, we wonder if 
theorizing can legitimately include simply making rhe-

torical arguments, as Dressman (2007) and Parsons

et al.

(2016) documented is often the case. Further, declaring

allegiance to a particular perspective or justification

in

advance of designing studies and collecting data invites

theory-laden perception, perhaps increasing the

likeli-

hood that researchers will find what they already

presume

to exist.

One example is new literacies, which is often

referred

to ambiguously as a theoretical perspective or

emerging

theory, notably in a lengthy edited volume (Coiro et

al.,

2008). The editors of that volume defined new

literacy

theory as a set of assertions, arguing that digital

texts,

especially on the internet, (a) require new skills, strate-

gies, and dispositions; (b) are increasingly central to

full

civic and economic participation; (c) are rapidly

changing

and evolving; and (d) are multimodal and

multifaceted.

These assertions comprise a coherent rationale for

con-

ducting research that addresses a certain domain of

ques-

tions and issues, and a researcher may reasonably

signal

agreement with them. These assertions might also be

use-

ful rhetorically to argue for more attention to the

broad

issues and challenges facing literacy educators that

arise

from forms of digital communication such as the internet

(e.g., International Reading Association, 2009).

Yet, alone, these assertions do not represent a produc-

tive theory in the sense of predicting or explaining spe-

cific phenomena or directly informing pedagogy. It is

one

thing to establish that there are aspects of literacy

merit-

ing our attention. It is another to generate theories

that help us understand them and inform us about how to deal with them pedagogically. For example, new literacies, in an expanded version, was offered as the theoretical perspective for a useful study convincingly reporting troubling differences between the online skills of readers from advantaged or disadvantaged schools (Leu et al., 2015). However, there was no theoretical connection that might account for those differences or what might be done to eliminate them.

A study by Lewis and Fabos (2005) illustrated how new literacies might be more productively combined with other theory. They used new literacies, along with literacy as social practice, as a general orientation and rationale for their study of adolescents' views about and use of instant messaging. However, going beyond that orientation, Lewis and Fabos used identity theory as a more specific interpretive frame to productively understand their data. That is, their findings and interpretations expanded that theory productively into the domain of pedagogy by theorizing that adolescents saw instant messaging in school as intruding on their nonacademic social identities outside of school.

In contrast, if new literacies (perhaps also disciplinary literacy: see Hinchman \& O'Brien, 2019; and translanguaging: see Wei, 2018) were presented as a perspective 
transefforts. 13 instead of a theory, it might then be productively

lated into new curricular goals and instructional activities.

In fact, there is evidence of movement in that direction.

For example, Coiro (2020) referred to new literacies

as a

perspective, not a theory. Likewise, Leu, Kinzer, Coiro, Castek, and Henry (2017) referred to new literacies as a

theory not only of literacy but also of instruction and assessment and identified broad areas of skills and dispo-

sitions that need to be taught. Yet, to move fully into the

domain of productive theory, there needs to be theorizing

about how those curricular and instructional goals can be

achieved or what inhibits such

\section{Frame Theorizing as a Dialectic}

This proposal has two dimensions. First, it reinforces Dressman's (2007) recommendation that theory should

serve as a dialectical scaffold, defined as a "persistent ten-

sion between the theory used and the data collected" (p.

347). In that sense, productive theorizing means taking a

more open, if not skeptical, stance where data can push

back against theory and where researchers are more will-

ing to see the limitations or inadequacies of their theories.

It means placing theory itself under investigation, partic-

ularly in regard to its practical utility, as we argue

here. It

means a conscious effort to avoid the pitfalls of

theory-

laden perception and incommensurability. Also, it

means

engaging in dialogue with researchers to cross

boundaries

of theory and method (see Almasi, 2016),

acknowledging

common goals and committing to bridging differences

toward achieving them.

A second dimension is adopting Dewey's view that

knowledge and practice are inextricably linked along a continuum, instead of conceptualizing knowledge as 14 | Reading Research Quarterly, 0(0) being separate from practice where it is then applied

(Biesta \& Burbules, 2003). It also means being aware and respectful of practitioners' theories of practice and not ascribing low status to those theories (Cochran-Smith \&

Lytle, 1999; Harste \& Burke, 1977). If a productive dialec-

tic about theory is to be opened up between researchers

and practitioners, we believe that researchers must attend

to and respect practitioners' theories of practice. A first

step might be to recognize that some theories in the field's

literature today, particularly those about rather than for

literacy and imported from other fields, are not, at least

not yet, conversation starters with practitioners. We believe that considering productivity suggests that a use-

ful next step would be to consider how such theories

might be presented meaningfully to practitioners and policymakers.

That is not to ignore that practitioners' theories of practice may be wrong, unwarranted, ineffective, or mis-

guided. Productive theorizing also includes identifying when theories of practice conflict with research data or ignore useful perspectives about literacy, determining 
how practitioners may be motivated to engage in more enlightened pedagogy, and refining useful theories of teacher change. It may also include developing respectful ways to nudge practitioners further toward the more abstract about literacy end of the continuum in Figure 1 or, as Biesta and Burbules (2003) argued, to get theory meaningfully into the minds of educators.

\section{Other Avenues to Productive Theorizing}

The previous proposals are only preliminary, and we hope our colleagues will expand, extend, and debate them. In this section, we provide a few other potential avenues toward increasing productive theorizing that merit fur- ther consideration. For example, some methodological approaches are more accommodating of the productive theorizing we envision. In addition to the phenomeno- logical methods alluded to in a previous section, design- based research (Cobb et al., 2003; McKenney \& Reeves, 2012; Reinking \& Bradley, 2008) is naturally aligned with developing theories of practice. Such methods address Pressley et al.'s (2006) argument that literacy researchers should attend more to understanding the processes, not just the outcomes, of classroom interventions.

Another possibility is deemphasizing a priori theories in framing research, which may help avoid the risks of investing uncritically in an established theory. Instead, researchers could focus on observed phenomena and puzzling results and then theorize about possible causes, which historically has been a more generative and pro- ductive approach in the physical sciences (Firestein, 2012; Stokes, 1997). In fact, Sloman and Fernbach (2017) found that being exposed to causal explanations in advance restricts consideration of a full range of explanations. Further, they argued that causal thinking is less sophisti- cated and less productive than diagnostic thinking, the latter being more divergent, creative, and generative and arguably more attuned to the goals of a practice-oriented field.

A view of productive theory as instrumentally predic- tive also suggests alternative ways of collecting, analyzing, and interpreting data in relation to testing and refining theory. For example, abduction, introduced by the phi- losopher Peirce (see McKaughan, 2008), extended deduc- tive and inductive reasoning into a less logic-bound domain. In its simplest form, abduction is an educated guess serving as a most likely explanation or as a prag- matic rule of thumb (see Dillon et al., 2000). Successive replications of a rule of thumb make guesses more edu- cated. Such an approach aligns with Bayesian statistics, an alternative to the frequentist approaches to quantitative analysis employed in education research. In Bayesian sta- tistics, an expanding array of objective and subjective data is quantified and then accumulated across studies/cases 
toward making increasingly accurate predictions. The potential of that approach was recognized in 2011, when the Institute of Education Sciences funded a three-year project to explore the use of Bayesian statistics in educa- tion research (Kaplan, 2011).

\section{Can the Field Embrace Productive Theorizing?}

We realize that the perspective we propose here may threaten the status quo. Theory, we believe, has been left comfortably unexamined, undifferentiated, and amor- phous in the field's literature for many decades (Calfee, 2014). The only unwavering imperative is that all research in the field mustbetheoretical in somesense. Conveniently, there is a broad array of recognized theories across many disciplines from which to choose. Also convenient is that there has been little impetus to explicitly consider what exactly counts as theory, what purposes it serves in achiev- ing the field's ultimate goals, and how it relates to methodological issues in collecting, analyzing, and interpreting data. In short, theory has existed too comfortably apart from any dedicated commitment to considering how it might be more, or less, productive in moving the field for- ward toward well-defined goals.

The status quo permits researchers to select theories that they find personally appealing and consistent with their interests, perspectives, and preferred research agen- das. It does not hold researchers explicitly accountable for the productivity of their theorizing. Thus, some research- ers may feel uncomfortable leaving a space where theory captures their passionate imaginings of a better future (Dressman, 2007), where it represents a stimulating intel-lectual perspective, or where it aligns them with like- minded researchers (Parsons et al., 2016). Yet, as we have argued, that comfortable space too often provides little explicit guidance for how theory might inform practice. In this commentary, we argued that explicitly considering theory as instrumentally productive in a practice-ori- ented field may mitigate these shortcomings and address the gap between research and practice.

We have no illusions about the difficulty of convinc- ing our colleagues to make such a transformation in their approach to theory. In many cases, it will likely make their theorizing and research, at least initially, more burden- some, necessarily more nuanced, and less driven by per- sonal beliefs. However, we wish to emphasize again that it does not mean abandoning theories about rather than for literacy or theories from other disciplines. It means, how- ever, accepting that such theories cannot be isolated from the pragmatic needs of instructional practice, especially for those who claim to be literacy researchers doing research for literacy under the 16 | Reading Research Quarterly, 0(0) umbrella of education research. It means a commitment to translating theory 
about literacy into terms that practitioners can under-

stand, appreciate, and apply in their work. It means

put-

ting theories in harm's way to discover where they

are

inadequate or where they break down.

Our position does not require abandoning the intellec-

tual stimulation of academic theorizing. From our own

experience, we find that there is nothing more intellectually

stimulating than trying to contemplate what does or does

not work in practice and why. In fact, theory that exists

too

comfortably, or too firmly, in an individual's work may

do

just the opposite: create a stagnating, stifling, and ultimately

unproductive posture.

There are encouraging signs that the time is ripe for

reconceptualizing and thinking more critically about

theory. For example, Snow (2015) bluntly stated that

"the

awful reputation [of education research] can be traced,

at least in part, to its alarming fecklessness" (p.

461). She

advocated for what she called practice-embedded

educa-

tion research (see also Coburn \& Penuel, 2016), in

which

the role of theory and research become more

aligned

with practice-oriented fields such as medicine,

agricul-

ture, and highway safety. Further, the Institute

of

Education Sciences in the U.S. Department of

Education

now includes both technical and practice reviewers

on

panels for grant funding (Feuer et al., 2016). In a

news-

letter, Schneider (2019), the director of the institute,

stated, "I want to emphasize how we are focusing on

the

mission of IES [Institute of Education Sciences] as

an

applied research agency" (para. 3). As these sources

sug-

29

gest, the issues we highlight here are clearly broader

than literacy research, applying to education research in general. Yet, they also create an opportunity for literacy researchers to lead the way for colleagues in related disciplines and fields of education.

More productive theorizing is unlikely to occur without dedicated action that values and nurtures it, beginning with the development of doctoral students and new scholars. The next generation of researchers needs more than methodological expertise and a menu of potential theories from which to claim their own. They need a clear understanding of a practice-oriented field's ultimate goals and how research and theory may productively serve those goals. They need an abiding commitment to bridging the chasm separating theory/research and practice. Theyneed permission to draw on their craft knowledge, often derived from their own experiences as classroom teachers. Also, they need opportunities to critique theories and studies along the dimensions of productivity highlighted in this commentary, most appropriately in courses and seminars focusing on theory in literacy research. Proposal and dissertation defense committees should expect doctoral candidates to explain specifically not only what theory or theories they are drawing on but also questions regarding in what sense their theory is productive, how their line of research connects to practice, and so forth. 
Likewise, editors and reviewers need to hold researchers accountable for how the theories that anchor their work productively serve the goals of a practiceoriented

field. Researchers should explicitly state and justify how

theory is positioned conceptually in relation to the research conducted and reported. Is theory used to explain phenomena, predict outcomes, reveal unknown or neglected aspects of literacy, inform pedagogy, express or argue an ideological position, provide a rationale for a

study, or other purposes? More importantly, researchers

should connect theory to research designs and to how

data are collected, analyzed, and interpreted, ideally with

a commitment to allowing data to push back against the

theory.

Further, there should be a heightened expectation

that research reports include a section on educational

or instructional implications. Publications committees

in our professional organizations and editors of jour-

nals should consider how to involve successful, experi-

enced, and knowledgeable practitioners in the peer review of research reports. When theories are imported into literacy research from other fields, the use and application of those theories should be reviewed by experts in the field of origin, or alternatively such experts should be included as coauthors with the literacy researchers.

We also need authoritative sources in the field that clearly state the role of theory and theorizing. More nuanced definitions of theory are needed with clarifica-

tion of hybrid terms such as theoretical framework, theo-

retical perspective, emerging theory, and theoretical model.

Weneed to move beyond accepting any theory or theo-

rizing as unquestionably appropriate or adequate simply

because it exists in the literature. We need to disabuse

ourselves of the notion that we are all free agents in select-

ing theories based solely on personal preference, intellec-

tual appeal, or connecting us to like-minded colleagues.

Also, we must hold one another accountable for explain-

ing how our theories serve the ultimate goals of a prac-

tice-oriented field.

Finally, we need to ask, and if necessary challenge, all

members of the literacy research

community to address

the questions and issues about theory that a consideration

of productive theorizing raises. To accept the status quois

to ignore the empirical findings suggesting that theory

has been problematic in the field's research literature and to cavalierly dismiss the long-lamented gap between the-

ory/research and practice. Accepting the status quo risks

allowing theorizing, as Dressman (2007) cautioned, to become an intellectual parlor game that is "a performance that matters mostly as a display of intellectual and cultural capital within the game itself and not the field as a whole

or the broader audience of practitioners and policy mak-

ers it purports to serve" (p. 349). Although he was optimistic that theory would evolve beyond such shallow 
purposes, we find little evidence that it has, now more than a decade later. Arguably, theorizing for its own sake may have become even more entrenched. Considering the productivity of the field's theorizing is one way to reverse that trend.

\section{NOTES}

We wish to acknowledge the following individuals for their helpful reactions to earlier drafts of this commentary: Kelly Chandler-Olcott, Georgia Earnest Garcia, Emily Howell, and George Hruby. However, this acknowledgment does not imply their endorsement of the content or their responsibility for any errors.

\section{REFERENCES}

Almasi, J.F. (2016). Crossing boundaries in literacy research: Challenges and opportunities. Literacy Research: Theory, Method, and Practice, 65(1), 2446. https://doi.org/10.1177/2381336916661542

Alvermann, D.E., Unrau, N.J., Sailors, M., \& Ruddell, R.B. (Eds.). (2019). Theoretical models and processes of literacy (7th ed.). New York, NY: Routledge.

Anders, P.L., Yaden, D.B., Iddings, A.C., Katz, L., \& Rogers, T. (2016). Improving theory in literacy research [Editorial]. Journal of Literacy Research, 48(1), 3-4.https://doi.org/10.1177/1086296X16637169

Ansari, D., Coch, D., \& De Smedt, B. (2011). Connecting education and cognitive neuroscience: Where will the journey take us? Educational Philosophy and Theory, 43(1), 37-42. https://doi.org/10.1111/j.1469- 5812.2010.00705.x

$\mathrm{Au}$, K.H. (1998). Social constructivism and the school literacy learning of students of diverse backgrounds. Journal of Literacy Research, 30(2), 297319. https://doi.org/10.1080/10862969809548000

Baker, L., Dreher, M.J., \& Guthrie, J.T. (Eds.). (2000). Engaging young readers: Promoting achievement and motivation. New York, NY: Guilford.

Bateson, G. (1979). Mind and nature: A necessary unity. New York, NY: E.P. Dutton.

Biesta, J.J., \& Burbules, N.C. (2003). Pragmatism and educational research. Lanham, MD: Rowman \& Littlefield.

Boote, D.N., \& Beile, P. (2005). Scholars before researchers: On the cen- trality of the dissertation literature review in research preparation. Educational Researcher, 34(6), 3-15.

Box, G.E.P., \& Draper, N.R. (1987). Empirical model-building and response surfaces. New York, NY: John Wiley \& Sons.

Boyles, D. (2012). Dewey, ecology, and education: Historical and contemporary debates over Dewey's naturalism and (transactional) realism. Educational Theory, 62(2), 143-161. https://doi.org/10. 1111/j.17415446.2012.00440.x

Bradley, B.A., \& Reinking, D. (2011). A formative experiment to enhance teacher-child language interaction in a preschool class- room. Journal of Early Childhood Literacy, 11(3), 362-401. https:// doi.org/10.1177/1468798411410802

Brown, A.L. (1992). Design experiments: Theoretical and methodolog- ical challenges in creating complex interventions in classroom set- tings. Journal of the Learning Sciences, 2(2), 141-178. https://doi. org/10.1207/s15327809jls0202_2

Brown, A.L., Armbruster, B., \& Baker, L. (1986). The role of metacog- nition in reading and studying. In J. Orasanu (Ed.), Reading com-prehension: From research to practice (pp. 49-76). Hillsdale, NJ: Erlbaum.

Bruer, J.T. (1997). Education and the brain: A bridge too far. Educa- tional Researcher, 26(8), 4-16. https://doi.org/10.3102/0013189X02 6008004

Bryk, A.S., Gomez, L.M., Grunow, I., \& LeMahieu, P.G. (2015). Learning to improve: How America's schools can get better at getting better. Cambridge, MA: Harvard Education Press. 
Bulterman-Bos, J. (2008). Will a clinical approach make education research more relevant for practice? Educational Researcher, 37(7), 412-420. https://doi.org/10.3102/0013189X08325555

Calfee, R.C. (2014). Introduction-knowledge, evidence, and faith: How the federal government used science to take over the public schools. In K.S. Goodman, R.C. Calfee, \& Y.M. Goodman (Eds.), Whose knowledge counts in government literacy policies? Why exper- tise matters (pp.1-17). New York, NY:Routledge.

Chambers, J.L. (1992). Empiricist research on teaching: A philosophical and practical critique of its scientific pretentions. Dordrecht, The Netherlands: Kluwer.

Chen, L.-C., Cheng, J.-C., \& Chou, M.-J. (2016). Literacy development in preschool children: A whole language curriculum. European Journal of Language Studies, 3(1), 24-49.

Cobb, P., Confrey, J., diSessa, A., Lehrer, R., \& Schauble, L. (2003). Design experiments in educational research. Educational Researcher, 32(1), 9-13. https://doi.org/10.3102/0013189X032001009

Coburn, C.E., \& Penuel, W.R. (2016). Research-practice partnerships in education: Outcomes, dynamics, and open questions. Educational Researcher, 45(1), 48-54. https://doi.org/10.3102/0013189X16631750 Cochran-Smith, M., \& Lytle, S.L. (1999). Relationships of knowledge and practice: Teacher learning in communities. Review of Research in Education, 24, 249-305.

Coiro, J. (2020). Toward a multifaceted heuristic of digital reading to inform assessment, research, practice, and policy. Reading Research Quarterly. Advance online publication. https://doi.org/10.1002/rrq.302 Coiro, J., Knobel, M., Lankshear, C., \& Leu, D.J. (2008). Central issues in new literacies and new literacies research. In J. Coiro, M. Knobel, C. Lankshear, \& D.J. Leu (Eds.), Handbook of research on new litera- cies (pp. 1-21). New York, NY: Erlbaum.

Colwell, J., Hunt-Barron, S., \& Reinking, D. (2013). Obstacles to devel- oping digital literacy on the internet in middle school science instruction. Journal of Literacy Research, 45(3), 295324. https://doi. org/10.1177/1086296X13493273

Colwell, J., \& Reinking, D. (2016). A formative experiment to align middle-school history instruction with literacy goals. Teachers College Record,118(12), 1-42.

Cunningham, J.W., \& Fitzgerald, J. (1996). Epistemology and reading. Reading Research Quarterly, 31(1), 36-60. https://doi.org/10.1598/RRQ.31.1.3

De Beaugrande, R. (1981). Design criteria for process models in read- ing. Reading Research Quarterly, 16(2), 261-315. https://doi.org/10. 2307/747559

Dillon, D.R., \& O’Brien, D.G. (2019). Pragmatism [not just] practicality as a theoretical framework. In D.E. Alvermann, N.J. Unrau, M. Sailors, \& R.B. Ruddell (Eds.), Theoretical models and processes of literacy (7th ed., pp. 582-600). New York, NY: Routledge.

Dillon, D.R., O’Brien, D.G., \& Heilman, E.E. (2000). Literacy research in the next millennium: From paradigms to pragmatism and practi- cality. Reading Research Quarterly, 35(1), 10-26. https://doi.org/10.1598/RRQ.35.1.2

Dressman, M. (2007). Theoretically framed: Argument and desire in the production of general knowledge about literacy. Reading Research Quarterly, 42(3), 332-363. https://doi.org/10.1598/RRQ.42.3.1

Elliott, J.G., \& Grigorenko, E.L. (2014). The dyslexia debate. New York, NY: Cambridge University Press.

Feuer, M., Neild, R.C., Carr, P., McLaughlin, J., Brock, T., \& Lesnick, J. (2016, April). Meet the Institute of Learning Sciences leadership. Session at the annual meeting of the American Educational Research Association, Washington, DC.

Feyerabend, P.K. (1970). Problems of empiricism. Cambridge, UK: Cambridge University Press.

Feyerabend, P.K. (2010). Against method (4th ed.). New York, NY: Verso.

Firestein, S. (2012). Ignorance: How it drives science. Oxford, UK:
Oxford University Press. 
Firestein, S. (2016). Failure: Why science is a success. Oxford, UK:

Oxford University Press.

Fleck, L. (1979). Genesis and development of a scientific fact (T.J.

Trenn

\& R.K. Merton, Eds.; F. Bradley \& T.J. Trenn, Trans.). Chicago,

IL:

University of Chicago Press.

Godfrey-Smith, P. (2003). Theory and reality. Chicago, IL: University of

Chicago Press.

González, N., Moll, L.C., \& Amanti, C. (2005). Funds of knowledge:

Theorizing practices in households, communities and classrooms.

New York, NY: Routledge.

Goodman, K.S., Fries, P.H., \& Strauss, S.L. (2016). Reading一the grand

illusion: How and why people make sense of print. New York,

NY:

Routledge.

Guthrie, J.T. (2004). Teaching for literacy engagement. Journal

of

hiteracy Research 36 dol.org 10.1207 s15548430j

lr3601_2

Gutiérrez, K.D., Morales, P.Z., \& Martinez, D.C. (2009). Re-mediating

literacy: Culture, cultural difference, and learning for students from

nondominant communities. Review of Educational Research, 33(1),

212-245. https://doi.org/10.3102/0091732X08328267 Hacking,I. (2012). Introductory essay. In T.S. Kuhn (Ed.), The

of scientific revolutions (50th anniv. ed., pp. vii-xxxvii). Chicago, IL:

University of Chicago Press.

Hanson, N.R. (1958). Patterns of discovery: An inquiry into the concep-

tual foundations of science. Cambridge, UK: Cambridge University

Press.
Harste, J.C., \& Burke, C.L. (1977). A new hypothesis for reading

research: Both the teaching and learning of reading is theoretically

based. In P.D. Pearson (Ed.), Reading: Theory, research and practice:

Twenty-sixth yearbook of the National Reading Conference (pp. 32-

40). Clemson, SC: National Reading Conference.

Heath, S.B. (1983). Ways with words: Language, life, and work in commu-

Bities and classrooms. Cambridge, UK: Cambridge University 27
ress.

From

Hinchman, K.A., \& O’Brien, D.G. (2019). Disciplinary literacy:

infusion to hybridity. Journal of Literacy Research, 51(4), 525-

536.

https://doi.org/10.1177/1086296X19876986

Hoadley, C.M. (2004). Methodological alignment in designbased

research. Educational Psychologist, 39(4), 203-212.

https:/2010iorg/s26985ep3904_2

Hoffman, J.V., \& Rutherford, W.L. (1984). Effective reading programs:

A critical review of outlier studies. Reading Research Quarterly,

\section{1}

20(1), 79-92. https://doi.org/10.2307/747653

Horwich, P. (Ed.). (1993). World changes: Thomas Kuhn and the nature of science. Cambridge, MA: MIT Press.

Hostetler, K. (2005). What is "good" education research? Educational Researcher, 34(6), 16-21. https://doi.org/10.3102/0013189X0340 06016

Howell, E., Butler, T., \& Reinking, D. (2017). Integrating multimodal arguments into high school writing instruction. Journal of Literacy Research, 49(2), 181-209. https://doi.org/10.1177/1086296X17700456

Hruby, G.G., \& Goswami, U. (2011). Neuroscience and reading: A review for reading education researchers. Reading Research Quarterly, 46(2), 156-172. https://doi.org/10.1598/RRQ.46.2.4

International Reading Association. (2009). New literacies and 21stcentury technologies [Position statement]. Newark, DE: Author. Retrieved from https://www.literacyworldwide.org/docs/defaultsource/where-we-stand/new-literacies-21st-century-position-state ment.pdf?sfvrsn=ec4ea18e_6

Kalantzis, M., Cope, B., \& Cloonan, A. (2010). A multiliteracies perspective on the new literacies. In E.A. Baker (Ed.), New literacies: Multiple perspectives on research and practice (pp. 61-87). New York, NY: Guilford.

Kaplan, D. (2011). Bayesian inference for experimental and observational studies in education (Institute of Education Sciences grant R305D110001). Retrieved from https://ies.ed.gov/funding/grantsearch/ details.asp?ID=1125 
Educational

15 https://doi.org/10.3102/0013189X0832

IL: educational https://doi.org/10. Yale

University Press. 293-323.

Education

5558 students. In D.E. models Reading Research 18. social https://doi.

org/10.1598/RRQ.40.4.5 controN.K. research IL:

translanguaging.

https://doi. learning 846.
Kuhn, T.(1962). The structure of scientific revolutions. Chicago,

University of Chicago Press.

Labaree, D.F. (2003). The peculiar problems of preparing researchers. Educational Researcher, 32(4), 13-22. 3102/0013189X032004013

Labaree, D.F. (2004). The trouble with ed schools. New Haven, CT:

LaBerge, D., \& Samuels, S.J. (1974). Toward a theory of automatic infor- mation processing in reading. Cognitive Psychology, 6(2) https://doi.org/10.1016/0010-0285(74)90015-2

Ladson-Billings, G. (1995). But that's just good teaching! The case culturally relevant pedagogy. Theory Into Practice, 34(3), 159https://doi.org/10.1080/00405849509543675

Lagemann, E.C. (2000). An elusive science: The troubling history of edu- cation research. Chicago, IL: University of Chicago Press.

Lagemann, E.C. (2008). Comments on Bulterman-Bos:

research as a distributed activity across universities.

Researcher, 37(7), 424-428.

Lee, C.D. (2013). Revisiting is October Brown Chinese? A cultural modeling activity system for understanding

Alvermann, N.J. Unrau, \& R.B. Ruddell (Eds.), Theoretical

and processes of reading (6th ed., pp. 265-296). Newark, DE: International Reading Association.

Leu, D.J., Forzani, E., Rhoads, C., Maykel, C., Kennedy, C., \& Timbrell,

N. (2015). The new literacies of online research and comprehension: Rethinking the reading achievement gap.

Quarterly, 50(1), 37-59. https://doi.org/10.1002/rrq.85

Leu, D.J., Kinzer, C.K., Coiro, J., Castek, J., \& Henry, L.A. (2017). New literacies: A dual-level theory of the changing nature of literacy, instruction, and assessment. Journal of Education, 197(2), 1-

https://doi.org/10.1177/002205741719700202

Lewis, C., \& Fabos, B. (2005). Instant messaging, literacies, and identities. Reading Research Quarterly, 40(4), 470-501.

Lincoln, Y.S., Lynham, S.A., \& Guba, E. (2018). Paradigmatic

versies, contradictions, and emerging confluences, revisited. In

Denzin \& Y.S. Lincoln (Eds.), Sage handbook of qualitative

(5th ed., pp. 108-150). Thousand Oaks, CA: Sage.

Linn, R. (1996). A teacher's introduction to postmodernism. Urbana,

National Council of Teachers of English.

MacSwan, J. (2017). A multilingual perspective on

American Educational Research Journal, 54(1), 167-201.

org/10.3102/0002831216683935

Mayer, R.E. (2017). How can brain research inform academic and instruction? Educational Psychology Review, 29, 835-

https://doi.org/10.1007/s10648-016-9391-1

\section{https://doi.org/10.17763/0017-8055.85.2.254}

50 Moll, L.C.(Ed.). (1990). Vygotsky and education:

Instructional implica-

51 tions and applications of sociohistorical psychology. Cambridge, UK:

$52 \quad$ Cambridge University Press.

Moll, L.C., \& González, N. (2004). Engaging life: A multicultural

approach to education. In J. Banks \& C.A.M. Banks (Eds.), Handbook of research on multicultural education (2nd ed., pp. 699-715). San Francisco, CA: Jossey-Bass.

22 | Reading Research Quarterly, 0(0) 
Morris, E. (2018). The ashtray (or the man who denied reality). Chicago, IL: University of Chicago Press.

Morrison, K.A., Robbins, H.H., \& Rose, D.G. (2008). Operationalizing culturally relevant pedagogy: A synthesis of classroom-based research. Equity \& Excellence in Education, 41(4), 433-452. https:// doi.org/10.1080/10665680802400006

Mosenthal, P.(1984). The problem of partial specification in translating reading research into practice. The Elementary School Journal, 85(2), 199-227. https://doi.org/10.1086/461401

Palincsar, A.S., \& Brown, A.L. (1984). Reciprocal teaching of comprehen- sionfostering and comprehension-monitoring activities. Cognition and Instruction, 1(2), 117-175. https://doi.org/10.1207/s1532690xc i0102_1

Parsons, S.A., Gallagher, M.A., \& Team, George Mason Content Analysis (2016). A content analysis of nine literacy journals, 2009-2014. Journal of Literacy Research, 48(4), 476-502. https://doi. org/10.1177/1086296X16680053

Payne, C.M. (2008). So much reform, so little change: The persistence of failure in urban schools. Cambridge, MA: Harvard University Press. Petroski, H.

(2012). To forgive design: Understanding failure. Cambridge, MA: Harvard University Press.

Phillips, D.C. (2009). A quixotic quest? Philosophical issues in assess- ing quality of education research. In P.M. Walters, A. Lareau, \& S.H. Ranis (Eds.), Education research on trial: Policy reform and the call for scientific rigor (pp. 163-196). New York, NY: Routledge.

Phillips, D.C., \& Burbules, N.C. (2000). Postpositivism and educational research. Lanham, MD: Rowman \& Littlefield.

Popper, K.R. (1959). The logic of scientific discovery. London, UK: Hutchison.

Pressley, M., Graham, S., \& Harris, K. (2006). The state of educational intervention research as viewed through the lens of literacy interven- tion. British Journal of Educational Psychology, 76(1), 1-19. https:// doi.org/10.1348/000709905X66035

Ranis, S.H. (2009). Blending quality and utility: Lessons learned from education research debates. In P.M. Walters, A. Lareau, \& S.H. Ranis (Eds.), Education research on trial: Policy reform and the call for sci- entific rigor (pp. 125-141). New York, NY: Routledge.

Reigeluth, C.M., \& Frick, T.W.(1999). Formative research: A method- ology for creating and improving design theories. In C.M. Reigeluth (Ed.), Instructional-design theories and models: Vol. 2. A new para- digm of instructional theory (pp. 633-651). Mahwah, NJ: Erlbaum.

Reinking, D., \& Bradley, B.A. (2008). On formative and design experi- ments: Approaches to language and literacy research. New York, NY: Teachers College Press.

Reinking, D., \& Watkins, J. (2000). A formative experiment investigat- ing the use of multimedia book reviews to increase elementary stu- dents' independent reading. Reading Research Quarterly, 35(3), 384-419. https://doi.org/10.1598/RRQ.35.3.4

Richards, R.J., \& Daston, L. (Eds.). (2016). Kuhn's structure of scientific revolutions at fifty: Reflections on a science classic. Chicago, IL: University of Chicago Press.

Ridley, L. (1990). Enacting change in elementary school programs: Implementing a whole-language perspective. The Reading Teacher, 43(9), 640-646.

Rodriguez, G.M. (2013). Power and agency in education: Exploring the pedagogical dimensions of funds of knowledge. Review of Educational Research, 37(1), 87-120. https://doi.org/10.3102/00917 32X12462686

Rosenblatt, L.M. (1968). Literature as exploration (Rev ed.). New York, NY: Noble \& Noble.

Rosenblatt, L.M. (1994). The transactional theory of reading and writ- ing. In R.B. Ruddell, M.R. Ruddell, \& H. Singer (Eds.), Theoretical models and processes of reading (4th ed., pp. 1057-1092). Newark, DE: International Reading Association.

Roth, W.M. (2009). Phenomenological and dialectical perspectives on the relation between the general and the particular. In K. Ercikan \& 
W.-M. Wolf (Eds.), Generalizing from educational research: Beyond qualitative and quantitative polarization (pp. 235-260). New York, NY: Routledge.

Rumelhart, D.E. (1977). Toward an interactive model of reading. In S. Dornic (Ed.), Attention and performance VI (pp. 503-531). Hillsdale, NJ: Erlbaum.

Rumelhart, D.E. (1985). Toward an interactive model of reading. In H. Singer \& R.B. Ruddell (Eds.), Theoretical models and processes of reading (3rd ed., pp. 722-750). Newark, DE: International Reading Association.

Samuels, S.J. (1979). The method of repeated readings. The Reading Teacher, 32(4), 403-408.

Samuels, S.J. (1981). Characteristics of exemplary reading programs. In

J.T. Guthrie (Ed.), Comprehension and teaching: Research reviews

(pp. 255-273). Newark, DE: International Reading Association. Sandoval, W.A. (2004). Developing learning theory by refining conjec-

tures embodied in educational designs. Educational Psychologist, 39(4), 213-223. https://doi.org/10.1207/s15326985ep3904_3

Schneider, M. (2019, April). First year accomplishments [Institute of Education Sciences director's remarks]. Retrieved from https://ies. ed.gov/director/remarks/4-23-2019.asp\#

Scott-Weich, B., \& Yaden, D.B., Jr. (2017). Scaffolded writing and early literacy development with children who are deaf: A case study. Early Child Development and Care, 187(3/4), 418-435. https://doi.org/10. 1080/03004430.2016.1246446

Sleeper, R.W. (1986). The necessity of pragmatism: John Dewey's concep- tion of philosophy. New Haven, CT: Yale University Press.

Sloman, S., \& Fernbach, F. (2017). The knowledge illusion: Why we never think alone. New York, NY:Riverhead.

Smagorinsky, P. (2011). Vygotsky and literacy research: A methodologi- cal framework. Amsterdam, The Netherlands: Sense.

Snow, C.E. (2015). Rigor and realism: Doing educational science in the real world. Educational Researcher, 44(9), 460-466. https://doi. org/10.3102/0013189X15619166

Stokes, D.E. (1997). Pasteur's quadrant: Basic science and technological innovation. Washington, DC: Brookings Institution Press.

Suppes, P. (1974). The place of theory in educational research. Educational Researcher, 3(6), 3-10. https://doi.org/10.3102/00131 89X003006003

Thomas, G. (1997). What's the use of theory? Harvard Educational Review, $67(1)$ https://doi.org/10.17763/haer.67.1.1x807 532771w5u48

Tracey, D.H., \& Morrow, L.M. (2017). Lenses on reading: An introduc- tion to theories and models (3rs ed.). New York, NY: Guilford.

Trimbur, J. (2013). The call to write (6th ed.). Boston, MA: Cengage.

Unrau, N.J., Alvermann, D.E., \& Sailors, M. (2019). Literacies and their investigation through theories and models. In D.E. Alvermann, N.J.
Unrau, M. Sailors, \& R.B. Ruddell (Eds.), Theoretical models and processes of literacy (7th ed., pp. 3-34). New York, NY: Routledge. Wagner, J. (1993). Ignorance in educational research or, how can you not know that? Educational Researcher, 22(5), 15-23. https://doi.org/ 10.3102/0013189X022005015

Walker, D. (2006). Toward productive design studies. In J. van den Akker, K. Gravemeijer, S. McKenny, \& N. Nieveen (Eds.), Educational design research (pp. 8-13). New York, NY:Routledge. Wei, L. (2018). Translanguaging as a practical theory of language. Applied Linguistics, 39(1), 9-30. https://doi.org/10.1093/applin/amx039

Willingham, D. (2008). When and how neuroscience applies to education. Phi Delta Kappan, 89(6), 421-423. https://doi.org/10.1177/ 003172170808900607

Yaden, D.B. (2017, June). Reintroducing Marxist thought back into new literacy theorizing. Paper presented at the 47th annual meeting of the Jean Piaget Society, San Francisco, CA.

Yaden, D.B., Jr., Gort, M., Martinez, C., \& Rueda, R. (2019). The education of young emergent bilingual children: An update and call for action. In O. Saracho (Ed.), Handbook for research on the education ofyoung children (4th ed., pp. 234-253). New York, NY: Routledge. Yaden, D.B., Jr., Rueda, R., Tardibuono, J., Martinez-Yaden, C., Mirzaei, A., Scott-Weich, B., \& Tsai, T. (2015). Interviewing young children using psycho- and micro-genetic design methodology to assess understandings of reading and writing: The promise and challenge. In O. Saracho (Ed.), Handbook of research methods in early childhood education: Review of research methodologies (Vol.2, pp. 309348). Charlotte, NC: Information Age.

Submitted April 29, 2019

Final revision received March 31, 2020

Accepted March 31, 2020

DAVID REINKING (corresponding author) is semiretired with a courtesy appointment in the Department of Language and Literacy Education at the University of Georgia, Athens, USA; email david.reinking@uga.edu. His published research typically reports formative experiments conducted to develop pedagogical theories that inform how digital forms of reading and writing can be integrated into literacy instruction.

DAVID B. YADEN, JR. is a professor in the Department of Teaching, Learning and Sociocultural Studies at the University of Arizona, Tucson, USA; email dyadenjr@arizona.edu. His primary research interests are literacy and biliteracy in young children, epistemological issues in literacy studies, and the application of systems theory to growth in reading and writing. 